\title{
Restoring and emulsifying properties of the dried meat semi-finished product
}

\section{Oleksandra Niemirich ${ }^{1}$, Mykola Pogozhich ${ }^{2}$, Oksana Petrusha ${ }^{1}$, Andrii Havrysh ${ }^{1}$, Oksana Vasheka ${ }^{1}$}

1 - National University of Food Technologies, Kyiv, Ukraine

2 - Kharkiv State University of Food Technology and Trade, Kharkiv, Ukraine

Keywords:

Meat

Emulsion

Semifinished

Drying

Mixed

heatpendencies

Porosity

\section{Article history:}

Received 04.02.2017

Received in revised

form 19.05.2017

Accepted 23.06.2017

Corresponding

author:

Oksana Petrusha

E-mail:

petrushaoo@ukr.net

DOI: $10.24263 / 2304-$

974X-2017-6-2-11

\section{Abstract}

Introduction. The technological properties of the dried meat semi-finished product (SFP) made by the DMSF-drying (mixed heat supply) method are studied, on the basis of which the mathematical dependence of the complex characteristic of the SMC on the drying temperature and the degree of product dispersion is difficult.

Materials and methods. The materials of researches were: beef meat vivarene and dried by convective method, as control, and dried meat semi-finished product of high degree of readiness, obtained by the mixed heat-transfer method. Based on the results of analysis of the spectra obtained by the IRspectroscopy method, changes in the chemical composition of the dried meat semi-finished product and after its reduction are characterized. The volume and average diameter of the pores of the dried meat semi-finished product were characterized with sorption-desorption isotherms obtained by the weight method.

Results and discussion. The researches complex of technological properties of the dried meat semi-finished product showed that using the drying method with mixed heat-water reducers promotes obtaining the product with a lower moisture content (twices) and improved its ability to restore while maintaining a high water-holding capacity (compared to the control, the water-holding capacity is more by $7,2 \%$ ) and the coefficient of water absorption (more than 1,3 times). The production of dried meat semi-finished products by the method of mixed heat-reduced content of volatile aromatous substances in comparison with the control is 1.3 times higher.

The analysis of the IR absorption spectra of dried meat semifinished product in the region of deformation vibrations of $\mathrm{OH}$ groups indicates that drying with mixed heat and water conductivities contributes to the formation of a capillary-porous structure that allows to increase the amount of adsorption-bound water by 1,5 times, and causes high rehydration and emulsification properties finished semi-finished product. The mathematical model of formation of the complex indicator of technological properties of the dried meat semi-finished product depending on the drying temperature and the degree of grinding of the semi-finished product is obtained.

Conclusions. The formation of high technological properties of the dried meat semi-finished product is established. The obtained data make it possible to recommend the semi-finished product as an independent product for a wide range of food products. 


\section{Introduction}

We know that the drying process, due to the realization of which the original properties of the materials should be kept as much as possible. Therefore, to the formation of functional and technological properties of the dried raw materials, a drying method with mixed heat and water (DMSF-drying) was used. This method, as shown in the review of the literature, is characterized by small economic and raw materials costs, and the final product is characterized by increased consumer properties compared to products obtained by other methods close to native raw materials [1-2].

For this drying method, a functional container with mass exchange gaps is used, in which the raw material is located, is dewatered. At the same time, the main heat flux to the evaporation zone of moisture flows through the heat exchange wall of the FM under conditions of a certain flow velocity of the mass exchange gap by the drying agent (steamair mixture). The driving force of heat transfer is the process temperature gradient. Heat is dissipated in the raw material zone, where the maximum intensity of evaporation of moisture is noted.

The conditions of the DMSF -drying for the preservation of vitamins are due to the low integral temperature effect on the raw material, the short duration of the process, the isolation of the raw material from the intensive action of the drying agent and light [1-4].

The above features of the implementation of the method of drying with mixed telopehydrates have made it necessary and expedient to use it to form the functional and technological properties of animal raw materials (beef meat) and vegetable (vegetable) origin.

Thus, dried dried meat is prepared in a high degree of preparedness.

DMSF is a concentrate of biologically active compounds, natural raw materials, has a long shelf life, has a pleasant smell, flavor, increases the nutritional and biological value of the diet, can act as an independent product and additive to some food products [5].

Formulations and technology of a dry mix, which is obtained from meat, vegetables and thickener, are known. It is reconstituted in water and used in the form of minced meat for floury culinary products. This mixture is stored for 18 months. In vacuum packing [67]. However, there are various ways to make it using the method of convection drying.

Therefore, the aim of this research was to study the recovery and emulsifying properties of DMSF for further justification of the valuation and the method of its introduction in multicomponent food system.

\section{Materials and methods}

\section{Materials}

Materials of the research in the article were: beef boiled meat and dried by convective method, as control, and dried meat semi-finished product of high degree of readiness, obtained by the mixed heat-transfer method, as a prototype. To compare the properties and composition of powders, the IR spectroscopy method is used where the IR spectra give a chemical composition by the number and position of peaks in the reflection (or absorption) spectra, indicating the nature of the substance, that is, a qualitative analysis is carried out, and the intensity of the bands is about Amount of substance, that is, quantitative analysis. 


\section{Methods}

IR absorption spectra were recorded for the grinded powdered samples, the optical element is a diamond, the angle of the incident beam $\theta=45^{\circ}$. Range $4000-400 \mathrm{~m}^{-1}$, number of scans -128 , a resolution of $0.04 \mathrm{~m}$. The background was recorded relative to the optical element without the sample.

The penetration depth of the infrared radiation into the sample $\left(d_{e}\right)$ as a function of the radiation wavelength $(\lambda)$ was calculated from the formula:

$$
d_{e}=\frac{\lambda}{2 \pi n_{O} \sqrt{\left[\sin ^{2} \theta-\left(\frac{n_{S}}{n_{O}}\right)^{2}\right]}}
$$

where $n_{s}$ - refractive index by sample; $n_{o}-$ by optical element $[8,9]$.

The removal of the vapor adsorption isotherms of dried objects was carried out by the gravimetric method in a vacuum plant with spring quartz scales Mack-Ben [10-17]. The isotherms were represented graphically:

where $a$ - value of adsorption in $\mathrm{mm} / \mathrm{g}$,

$$
a=f(P / P S)
$$

$P / P S$ - relative vapor pressure of adsorbent.

On the basis of experimental isotherms of adsorption-desorption were calculated specific surface of the sample $\mathrm{S}$, the maximum sorption pore volume Vs average pore diameter $\mathrm{D}$.

The value of the specific surface of the samples was calculated from the isotherms of vapor adsorption by the method of multi-molecular theory of adsorption of vapors of Brunauer, Emmett and Teller (BET method).

The water absorption coefficient (CV) of the samples was determined using a Dogadkin device (Figure 1) [18], which consists of a funnel 1 connected by the principle of communicating vessels with a graduated tube 2 . The connecting path is an extension 3, which is a receiver for replenishing the liquid. In the lower part, the connecting tube has a branch 4 with a rubber tube and a clip 5 . The tap serves to start water from the system at the end of work.

The graduated tube has a right angled bend 6 from

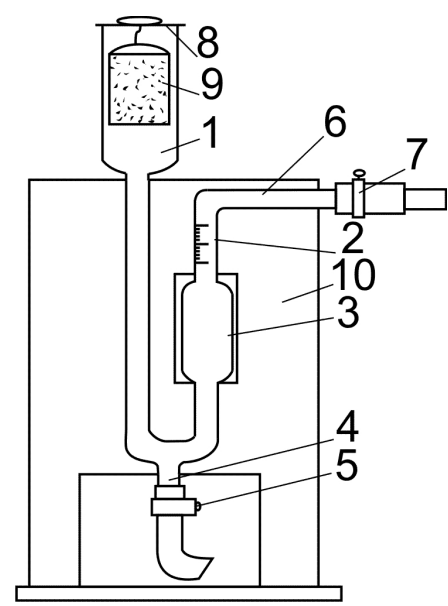

Figure 1. Installation of Dogadkin the rubber tube and the clamp 7. The funnel is covered with a lid 8 with a hook on which the wire mesh 9 is suspended, into which the sample of the research material is placed. If the phone is not calibrated and there is a scale on the instrument board with millimeter paper, the linear scale of the tube may not correspond to the volume amount of water in it.

In this case, the device must be pre-graduated and indicate the conversion factor on which the linear scale should be multiplied in order to obtain volumetric values.

Graduations of the device are carried out in the following way: in a device installed on a flat surface, water is poured to the bottom of the scale, burettes with water are placed 
above the funnel of the instrument, from which 0,005 liters of water are added to the device and the level of water in the tubes is marked on the scale of the device in parallel.

The obtained values are recorded. Water from the burette is added until it rises to the upper division of the scale. Then, the water from the device is poured out through the tap 4 and the calibration is repeated. Of the three calibration measurements, an average value is output, which sets the scale division price and the conversion factor.

The water binding capacity (WBC) of the samples was determined by the pressing method. A crushed sample of $0,003 \mathrm{~kg}$ was weighed on a torsion balance on a polyethylene plate $0,015-0,020 \mathrm{~m}$ in diameter. The sample was transferred to a filter placed on a glass plate so that the sample was under a polyethylene mug. On top, the sample was covered with the same plate and a weight of $1 \mathrm{~kg}$ was placed and held for 10-60 s. After this, the filter with a sample was released from the load and the upper plate and a contour of the spot around the compressed sample was applied to the filter with a pencil. The outer contour is visible when the filter paper is drying in air.

With the aid of a planimeter, the spot area of $0,01 \mathrm{~m}^{2}$, determined by the reconstituted sample and moisture, which was absorbed into the filter paper, was determined. The size of the wet spot was expressed as the difference between the area of the wet spot and the area of the spot formed by the sample.

It was experimentally established that $0,01 \mathrm{~m}^{2}$ of the area contains $0.0084 \mathrm{~kg}$ of water. The composition of the bound moisture (in \% to the sample) was determined by the formula [19].

$$
X=\frac{(M-8,4) \cdot S}{m} 100, \%
$$

where $X$ - bound moisture content, $\%$;

$M$ - moisture content in the sample, $10^{-3} \mathrm{~kg}$;

$S$ - wet spot area, $0,01 \mathrm{~m}^{2}$;

$m$ - batch weight, $10^{-3} \mathrm{~kg}$.

In the study of the water-retaining capacity (WRC) of powders, a weight method was used. To do this, a sample of the powder was added to the centrifuge tube and water was added in a ratio of 1:20. The mixture was stirred and allowed to swell at $313^{\circ} \mathrm{K}\left(40^{\circ} \mathrm{C}\right)$ for $2 \cdot 60^{2} \mathrm{~s}$. After that, centrifugation was performed for $15 \cdot 60 \mathrm{~s}$ at a speed of $5000 \mathrm{~s}^{-1}$. The formed liquid over the precipitate was drained, having previously determined the content of solids by means of a refractometer. The mass of the wet residue remaining determined by weighing the WRC was determined by the formula:

$$
B=\frac{M_{B}}{M_{H} \times(100-\alpha)} \times 100, \%
$$

where $B-$ WRC of product, $\%$;

$M_{6}$ - a wet cake after centrifugation, $10^{-3} \mathrm{~kg}$;

$M_{H}-$ dry weight, $10^{-3} \mathrm{~kg}$;

$\alpha$ - correction factor, taking into account the content of dry matter in the supernatant, $\%$, determined by the formula:

$$
\alpha=\frac{\left(b-M_{B}\right) \times p \times 100}{c \times M_{H}},
$$

where 8 - the amount of water that was taken to prepare the suspension, $10^{-3} \mathrm{~kg}$;

$c$ - mass fraction of solids in powder, $\%$;

$p$-content of dry matter in the supernatant, $\%$ [20]. 
A $0,002 \mathrm{~kg}$ sample was placed in a porcelain mortar to determine the grease-resisting capacity (WRC) [21], to which $0,0025 \mathrm{~kg}\left(0,01 \mathrm{~m}^{3}\right)$ of fine calcined sand and $0,006 \mathrm{~kg}$ $\left(0,043 \mathrm{~m}^{3}\right) \alpha$-monobromonaphthalene were added. The contents of the mortar were carefully triturated for $4.60 \mathrm{~s}$ and then filtered through a folded paper filter.

The test solution (3-4 drops) was uniformly applied with a glass rod on the lower prism of the refractometer. The prisms were closed and fastened with a screw. A ray of light was directed with a mirror on the prism of the refractometer, setting the telescope so that the intersecting threads (Aliados) were clearly visible. The aliados were moved until the boundary between the illuminated and dark parts coincided with the point of intersection of the filaments, after which the refractive index was deducted.

The WRC was determined by the formula:

$$
W R C=\frac{g_{1}}{g_{2}} \cdot 100, \%
$$

where $g_{1}-$ mass fraction of fat in the sample after heat treatment, \%;

$g_{2}$ - mass fraction of fat in the sample for heat treatment, $\%$.

The mass fraction of fat in the sample was determined from formula:

$$
g=\frac{\left(10^{4} \cdot \alpha \cdot\left(n_{1}-n_{2}\right) \cdot m_{1}\right.}{m}, \%
$$

where $\alpha$ - the coefficient characterizing such a fat content in the solvent, which changes the refractive index by $0.0001 \%$;

$\mathrm{n}_{1}$ and $\mathrm{n}_{2}$ - refractive indices of the respectively pure solvent and test solution;

$\mathrm{m}_{1}$ - mass of $0,043 \mathrm{~m}^{3}$ of $\alpha$-monobromonaphthalene, $10^{-3} \mathrm{~kg}$;

$\mathrm{m}$ - weight of the brave, $10^{-3} \mathrm{~kg}$.

The emulsifying capacity (EC) of the samples was determined from the phase inversion point according to the method of Gurov O. [22]. For this, 0,01 liters of a suspension was placed in a 0,1 liter beaker, then oil was introduced with a divisible burette at a rate of (70-80) 60 drops $/ 60 \mathrm{~s}$ before the moment of inversion of the phases, that is, the transition of the oil / water emulsion into the water / oil emulsion. The type of emulsion was determined by dilution method. The volume of oil that is used from the burette corresponds to the value of the phase inversion point.

Aggregative stability (AS) of the emulsion was determined by fixing the volume of oil separated after centrifugation at a rotation speed of $1500 \cdot 60^{-1} \mathrm{~s}^{-1}$ for $5.60 \mathrm{~s}$. Then this tube was placed on a water bath for $3.60 \mathrm{~s}$ and again centrifuged for $5.60 \mathrm{~s}$. The value of AS was determined as the ratio of the volume of oil remaining in the emulsion to the total volume of oil in the emulsion

$$
\mathrm{AS}=\frac{V_{1}-\mathrm{V}_{2}}{V_{1}} \cdot 100 \%
$$

where $A S$ - aggregative stability of emulsion, \%;

$V_{l}$ - volume of fat phase in emulsion, $10^{-3} 1$;

$V_{2}$ - volume of fat phase, separated, $10^{-3} 1[20]$.

The content of soluble and water-soluble proteins in the DMSF was determined by conventional methods [23]. 
The two-factor experiment was used to construct the mathematical model for the formation of a complex indicator of the technological properties of a dried meat semifinished product, depending on the drying temperature and the degree of refinement of the semi-finished product. At the same time, the variation of the indices was within the range of temperatures from $50(-1)$ to $90(+1)^{\circ} \mathrm{C}$ and particle sizes from $35 \cdot 10^{-6}(-1)$ to $55 \cdot 10^{-6}$ (+1) $\mathrm{m}[24]$.

\section{Results and discussion}

Drying is the optimal method of producing shelf stable products while preserving their original quality without using preservatives or additives, because today, in the foreground, is the degree of naturalness and nutritional value of food products.

For the formation of technological properties of raw meat was used drying, as shown in the literature review, it is characterized by a small economic and commodity costs, and the final product is characterized by improved consumer properties compared to products obtained in other ways, similar to the native raw materials [1-2]. For this purpose beef previously boiled steamed, crushed, minced and dried by a new method. As a control sample in the studies selected boiled meat convection drying.

While drying, the nutritional value of meat from the point of view of the content of vitamins, irreplaceable amino acids is virtually unchanged in that time, as the physicochemical properties of muscular tissue in varying degrees, can affect the quality of the dried product.

Results of the research confirm that the majority of meat proteins are water soluble (moialbumin, myoglobin, globulin $-8,5 \%$ in meat of dried mixed method of draining drying and $5,8 \%$ in the convective drying of meat) and salt- soluble (actin, myosin and actomyosin $-51,2$ and $45,6 \%$, respectively) - Table 1 .

Table 1

Indicators of meat quality convective and dried mixed method of draining

\begin{tabular}{|l|c|c|}
\hline \multirow{2}{*}{\multicolumn{1}{|c|}{ Exponent }} & \multicolumn{2}{c|}{ Sample of the meat } \\
\cline { 2 - 3 } & $\begin{array}{c}\text { Convective drying } \\
\text { control }\end{array}$ & $\begin{array}{c}\text { Dried mixed } \\
\text { method of } \\
\text { draining drying }\end{array}$ \\
\hline Final moisture content, \% & $14,0 \pm 0,5$ & $7,0 \pm 0,5$ \\
\hline Fat content,\% & $3,3 \pm 1,0$ & $3,3 \pm 1,2$ \\
\hline CD, per unit value & $2,7 \pm 0,2$ & $3,4 \pm 0,1$ \\
\hline WHC, \% & $46,1 \pm 0,4$ & $53,3 \pm 0,5$ \\
\hline Duration of the recovery in the water - 60 & $40 \pm 5$ & $30 \pm 5$ \\
\hline Content of water-soluble protein, \% Br & $6,8 \pm 0,3$ & $7,5 \pm 0,5$ \\
\hline Contents salt-soluble protein, \% $\mathrm{Br}$ & $47,6 \pm 0,5$ & $51,2 \pm 1,5$ \\
\hline Contents of extractives, \% & $1,10 \pm 0,05$ & $1,30 \pm 0,05$ \\
\hline Number of flavor, units & $14,0 \pm 0,5$ & $18,0 \pm 0,5$ \\
\hline
\end{tabular}


As shown from Table 1, the meat dried mixed method of draining drying and the convective drying values are 1,3 times higher than in controls, which correlates with the index of water-holding capacity samples $(50,2 \%$ and $45,1 \%$ in the form of meat for the water temperature $(48 \pm 2)^{\circ} \mathrm{C}$. With and 46.1 and $53,3 \%$ in a divided state, respectively). The duration of the recovery control samples for $10 \cdot 60$ more and is $40.60 \mathrm{sec}$.

The number of flavor of meat dried mixed method of draining drying (18 units) is directly proportional with the content of extractives, which indicates the maximum preservation of aroma of boiled meat in comparison with the sample of convective drying, where the loss of volatile substances fragrant occurred to a greater extent.

The obtained data correlate with the results of studies on the use of IR spectra with the FTIR transformation using a spectrometer Nicolet Nexus 470.

In Figure 2 presents IR absorption spectra of boiled meat, meat dried mixed method of draining drying of native and restored to moisture boiled.

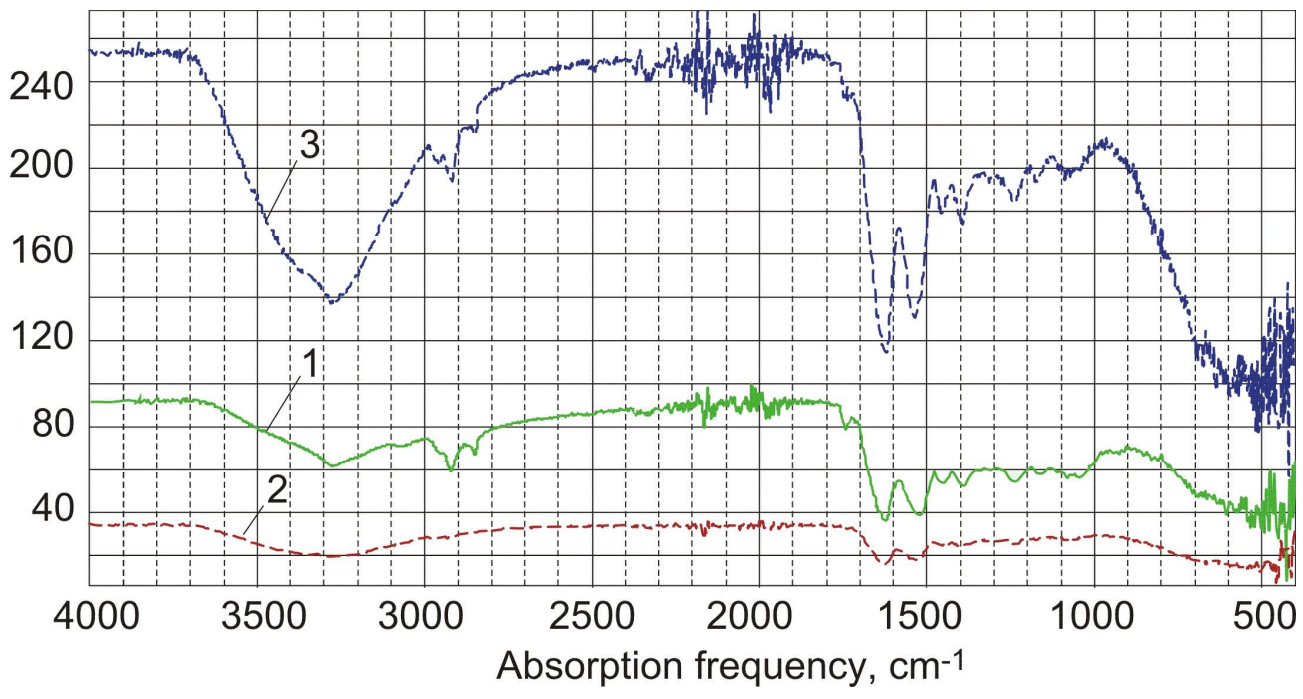

Figure 2. Infrared absorption spectra of meat:

1 - boiled the main method of control;

2 - dried mixed method of draining drying;

3 - dried mixed method of draining drying, restored to a moisture content of boiled.

IR spectra of the control (boiled meat) and test samples of meat, dried and restored in the frequency range from $3000-3600 \mathrm{~cm}^{-1}$, characteristic for stretching vibrations of functional groups $-\mathrm{OH}$ is involved in the formation of intramolecular and intermolecular hydrogen bonding of free and bound moisture, sugars and biopolymers, etc., indicate the increasing intensity of the spectra, and, consequently, the formation of additional hydrogen bonds in the meat dried mixed method of draining drying the recovered in comparison with the control.

Shown that in the frequency range 2900-2000 $\mathrm{cm}^{-1}$, characteristic for stretching vibrations of $\mathrm{NH}_{2}$ - and $\mathrm{NH}$-group, boiled meat and the meat recovered is observed the same intensity of absorption spectra. 
In the area of deformation vibrations - $\mathrm{OH}$ groups is the intensity of the absorption bands $1648,2 \mathrm{~cm}^{-1}$ in meat dried mixed method of draining drying the recovered 2.4 times more compared to the corresponding band in the control sample. The results indicate that dried mixed method of draining drying promotes to maximize the preservation of the original quality of the raw materials, the formation of capillary-porous structure, which allows to increase the number of bound water adsorption in 1,5 times more.

In the area of $1743 \mathrm{~cm}^{-1}$, characteristic for stretching vibrations of $\mathrm{C}=\mathrm{O}$ groups indicate the presence proxies, ketones and conjugated acyclic anhydrides in the product. There is an insignificant intensity of the absorption spectra of boiled beef and dried meat restored. This suggests that lipid peroxidation products do not formed during dried mixed method of draining drying.

Thus, dried mixed method of draining drying allows obtaining products with maximum preservation of nutritional and biological value in comparison with other drying methods that approximate products sublimation method.

For studies of porosity structure used a vacuum Mack-Ben - Figure 3 and Table 2.
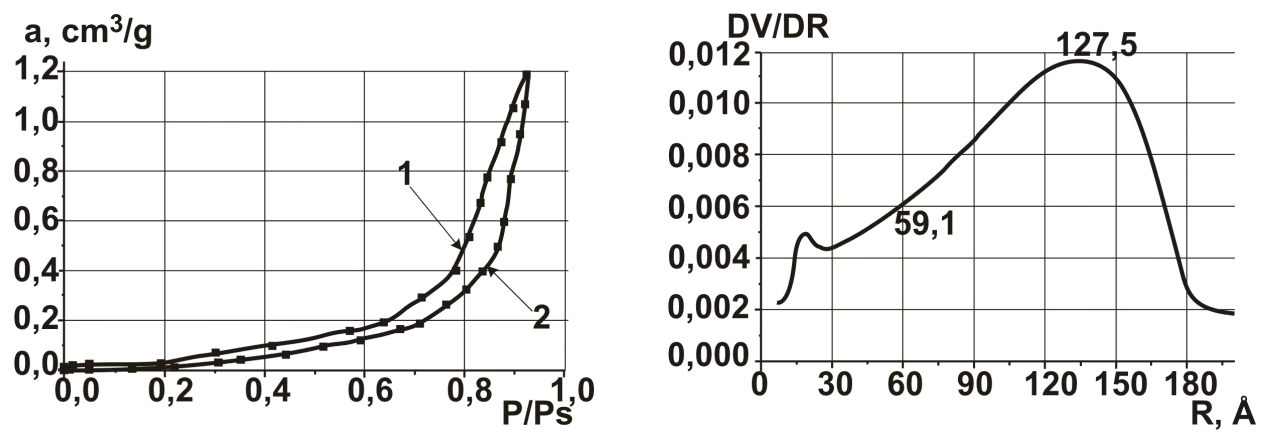

convection drying (control) meat

$a$

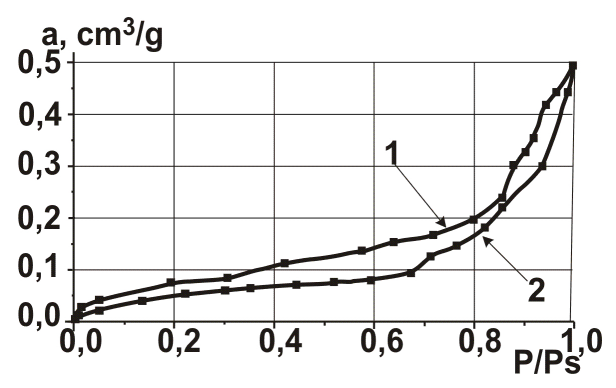

$\boldsymbol{b}$

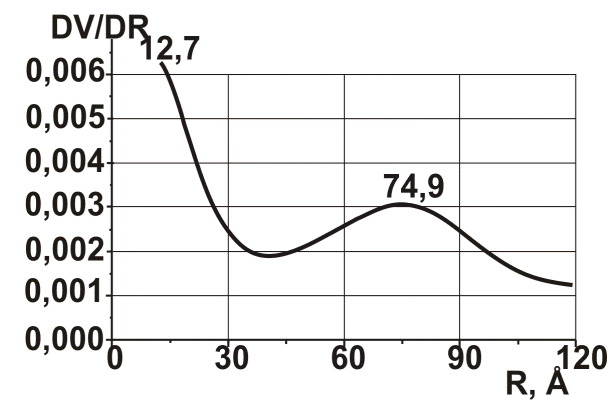

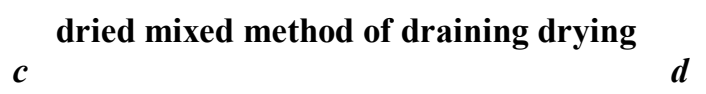

Figure 2. Adsorption isotherms of water vaporization (a, c) and the distribution of pores with radii $(b, d)$, DMS 1 - sorption; 2 - desorption 
Structural characteristics of DMSF that were filmed in water vapor

\begin{tabular}{|l|c|c|}
\hline \multirow{2}{*}{ Exponent } & \multicolumn{2}{c|}{ Value in the test samples } \\
\cline { 2 - 3 } & $\begin{array}{c}\text { Convective } \\
\text { drying control }\end{array}$ & $\begin{array}{c}\text { Dried mixed method of } \\
\text { draining drying }\end{array}$ \\
\hline Activation energy of water, $\mathrm{kJ} / \mathrm{mol}$ & 0,10 & 0,46 \\
\hline \multicolumn{2}{|c|}{ Structural characteristics: } \\
\hline Specific surface of the sample $\mathrm{S}, \mathrm{m}^{2} / \mathrm{g}$ & 196 & 171 \\
\hline $\begin{array}{l}\text { Standard error of calculation of the } \\
\text { surface } \mathrm{R}^{2}\end{array}$ & 0,95 & 0,91 \\
\hline Sorption pore volume, $\mathrm{Vs}, \mathrm{cm}^{3} / \mathrm{g}$ & 0,79 & 0,66 \\
\hline Pore diameter, $\mathrm{D}, 10^{-10}, \mathrm{~m}$ & 189 & 154 \\
\hline
\end{tabular}

As can be seen from Figure 3, the curve of sorption-desorption of DMSF below the curve of sorption-desorption control sample, indicating a smaller pore volume of the prototype. Moreover, the nature of the hysteresis loop in the control sample is first narrowed, and further observed its expansion, evidence of slow restoration of the structure of the sample in the liquid.

Loop is characterized by early expansion-contraction-expansion, allowing you to absorb and retain moisture to a greater degree than the control.

Structural characteristics of samples (tab. 2) show that the volume of pores in DMSF is $\mathrm{Vs}=0.66 \mathrm{~cm}^{3} / \mathrm{g}$, while sample convective drying indicator value equal to $\mathrm{Vs}=0.79 \mathrm{~cm}^{3} / \mathrm{g}$. This is also evidenced by the distribution curve of the pore radius where the curve distribution in a sample of DMSF below the curve of the sample of meat of convective drying, which indicates a greater number of pores (area under curve).

Thus, studies of capillary-porous structure of DMSF, obtained the dried mixed method of draining drying indicate a preference for the current porosity in comparison with meat convection drying.

For implementation concept of work on formation rehabilitation and emulsifying properties conducted complex researches: water absorption coefficient (WAC, units); water-holding capacity (WHC, \%); emulsifying capacity (EC, \%); aggregate stability (AS, $\%$ ); the number of flavor (NF) depending on the drying temperature and the degree of grinding dried mixed method of draining drying raw meat.

The absolute values of the specified technological properties were converted using the scale of Harrington in relative units. With mathematical processing of the results obtained by a conceptual mathematical model of the complex index of technological properties of DMSF. The surface response of this index to the temperature Figure 4. 


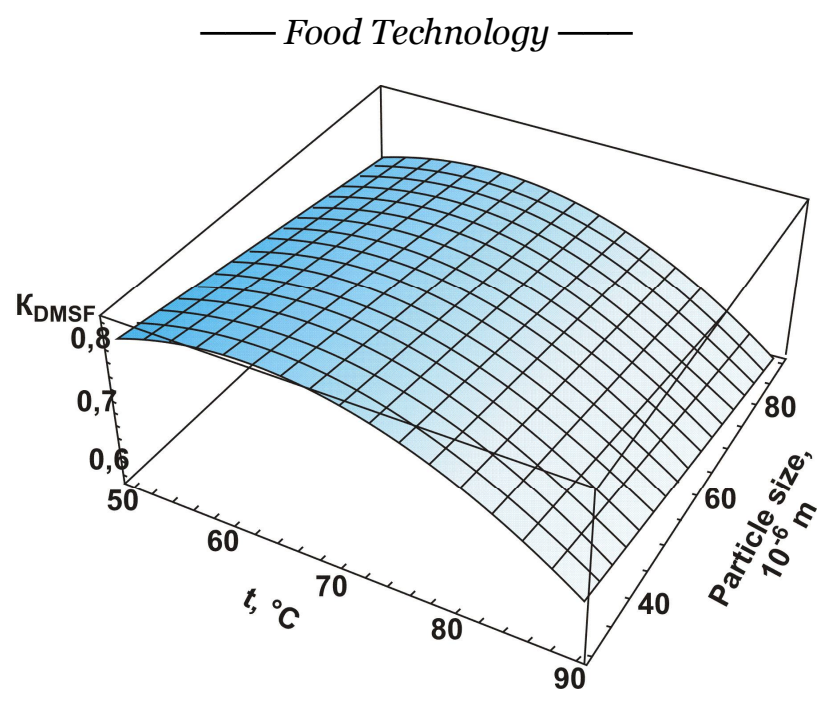

Figure 4. The surface response of a complex indicator of the technological properties of the temperature dried mixed method of draining drying and grinding degree of DMSF

A mathematical model of the formation of a complex indicator of technological properties of DMSF:

$$
Y=0,035626+0,0027608 x_{1}-0,001494 x_{2}-0,000223 x_{12}-0,000003 x_{22}+0,000002 x_{1} x_{2}
$$

The presented equation is adequate for DMSF at the temperature within the range of $50-90{ }^{\circ} \mathrm{C}$ and the particle dispersion is $35-85 \cdot 10^{-6}$.

Based on these data, formulated the potential of technological properties of the DMSF for use in technology of culinary products - Table 3 .

Table 3

The potential of functional and technological properties DMSF for use in technology of culinary products

\begin{tabular}{|c|c|c|}
\hline $\begin{array}{l}\text { Technological } \\
\text { properties }\end{array}$ & Functional properties & $\begin{array}{l}\text { The range of culinary } \\
\text { products }\end{array}$ \\
\hline \multirow[b]{2}{*}{$\begin{array}{l}\text { The minced particle } \\
\text { size }(5-6) \cdot 10^{-3} \mathrm{~m}\end{array}$} & \multirow{5}{*}{$\begin{array}{l}\text { Uniformity of mixing of dry bulk } \\
\text { materials, water-holding ability fat- } \\
\text { holding ability, aggregate stability }\end{array}$} & First and second courses \\
\hline & & $\begin{array}{l}\text { Flour culinary products } \\
\text { from meat and meat- } \\
\text { vegetable stuffing }\end{array}$ \\
\hline $\begin{array}{l}\text { Powder with a particle } \\
\text { size of }(90-200) \cdot 10^{-6} \mathrm{~m}\end{array}$ & & $\begin{array}{l}\text { Chopped products, } \\
\text { puddings }\end{array}$ \\
\hline$(60-90) \cdot 10^{-6} \mathrm{~m}$ & & Baked dishes (dumplings) \\
\hline$(30-60) \cdot 10^{-6} \mathrm{~m}$ & & Sauces, snacks, soufflé \\
\hline Recovery & Water-binding ability & $\begin{array}{l}\text { Toppings, stuffing for } \\
\text { baked food products }\end{array}$ \\
\hline $\begin{array}{l}\text { The flavor of cooked } \\
\text { meat }\end{array}$ & The number of flavor & Aromatic additive \\
\hline
\end{tabular}




\section{Conclusions}

1. It was shown minor changes in the chemical composition of the semi-finished product in comparison with the control sample by IR spectroscopy.

2. It was studied the porosity structure of DMSF. Proved that during the traditional convective drying there is a significant narrowing of the capillaries, due to shrinkage, while the dried product dried mixed method of draining drying has a porous structure, which causes to its high rehydration and emulsifying properties.

3. Complex research of technological properties of DMSF on which was found the mathematical dependence of the complex index depending on temperature dried mixed method of draining drying and degree of dispersion.

Acknowledgements. The work was carried out as part of the state budget research topic «Identification, assessment of quality and safety of food products by sensory systems with artificial intelligence» (state registration number $0115 \mathrm{U} 000378$ ).

\section{References}

1. Pohozhykh M.I., Holovko T.M., Polupan V.V., Bakirov M.P., Parkhomenko L.O. (2016), Obhruntuvannia tekhnolohii vyrobnytstva j-se funktsionalnoi dobavky $u$ vyhliadi poroshku, Scientific Works of the National University of food Technologies, 22(6), pp. 179-188.

2. Pohozhykh M.I., Pak A.O., Pak A.V., Zherebkin M.V. (2014), Vplyv parametriv rukhu sushylnoho ahenta na kinetyku sushinnia zmishanym teplopidvodom, VostochnoEvropeiskyi zhurnal peredovykh tekhnolohyi, 2(12), pp. 4-8.

3. Davidsson L., Dimitriou T., Walczyk T., Hurrell RF. (2001), Iron absorption from experimental infant formulas based on pea (Pisum sativum)-protein isolate: the effect of phytic acid and ascorbic acid, Br J Nutr, 85(1), pp. 59-63.

4. Hurrell RF. (2004), Phytic acid degradation as a means of improving iron absorption, Int J Vitam Nutr Res, 74(6), pp. 445-452.

5. Pogozhyx M.I., Yevlash V.V., Gavrysh A.V., Maksymenko A.Ye. (2013), Texnologichni aspekty vyrobnycztva sushenogo myasa, Scientific Works of the National University of food Technologies, pp. 21-28.

6. Pogozhyx M.I., Yevlash V.V., Gavrysh A.V., Maksymenko A.Ye. (2013), Doslidzhennya yakosti sushenogo myasa ta poroshkiv z myasa pid chas zberigannya $\mathrm{v}$ riznomu pakuvanni, Obladnannya ta texnologiyi harchovyh vyrobnycztv, 30, pp. 143148.

7. Evlash V.V., Maksimenko A.E., Gritsenko O.Iu. (2014), Formirovanie poristosti sushenogo miasa goviadiny pri STP-sushke, Visnik Natsionalnogo tekhnichnogo universitetu «KhPI», 7(1050), pp. 185-189.

8. Al-Muhtaseb A.H., McMinn W.A.M., Magee T.R.A. (2002), Moisture Sorption Isotherm Characteristics of Food Products: A Review, Food and Bioproducts Processing, 80(2), pp. 118-128.

9. Prech Je., Bjulmann F., Affolter K. (2006), Opredelenie stroenija organicheskih soedinenij. Tablicy spektral'nyh dannyh, Moscow.

10. Valérie Guillard,Claire Bourlieu, Nathalie Gontard (2013), Food Structure and 
Moisture Transfer: A Modeling Approach, Springer Science \& Business Media, London.

11. Tovbin Iurii (2012), Molekuliarnaia teoriia adsorbtsii v poristykh telakh, Moscow.

12. Tovbin Ju.K., Eremich D.V., Komarov V.N., Gvozdeva E.E. (2007), Raspredelenija molekul na granice razdela par-zhidkost v uzkih porah, Himicheskaja Fizika, 26(9), p. 98.

13. Jashkin S.N., Murashov B.A., Klimochkin Ju.N. (2011), Jeksperimentalnoe $i$ molekuljarno-statisticheskoe issledovanie adsorbcii molekul iodbenzola, 2-iodtiofena $i$ izomernyh iodadamantanov na poverhnosti bazisnoj grani grafita, Zhurnal fizicheskoj himii, 85(4), pp. 758-765

14. Faruk Civan (2011), Porous Media Transport Phenomena, John Wiley \& Sons, Inc.

15. Karge, Hellmut G., Weitkamp, Jens (2007) Adsorption and Diffusion, Springer Science $\&$ Business Media, Berlin.

16. Bileckii V.S. (2004), Mala girnicha enciclopediia, tom 1, Donbas, Donets.

17. Lowell, S., Shields, J.E., Thomas, M.A., Thommes, M. (2004), Characterization of Porous Solids and Powders: Surface Area, Pore Size and Density, Springer.

18. Rebinder P.A. (2009), Novaja tehnologija dispepsnyh matepialov, Vse materialy. Entsiklopedicheskij spravochnik, 5, pp. 2-10.

19. Krajnjuk L. N., Savgira Ju. A., Pozdnjakova E. B., Jancheva M. A. (2000), K voprosu o sovershenstvovanii metodiki opredelenija vodosvjazyvajushhej sposobnosti mjasa i mjasoproduktov, Progresivni tehnologii ta udoskonalennja procesiv harchovih virobnictv, 1, pp. 119-123.

20. Antipova L.V., Glotova I.A., Rogov I.A. (2001), Metody issledovanija mjasa i mjasnyh produktov, Kolos, Moscow.

21. Gurov N.V. Popelo I.A., Suchkov V.V. (2001), Metody opredelenija funkcional'nyh svojstv soevyh belkovyh preparatov, Mjasnaja industrija, 9, pp. 30-32.

22. Horalchuk A.B. Pyvovarov P.P. (2010), Tekhnolohiia termostabilnykh emulsiinykh sousiv na osnovi ovochevoi syrovyny, Kharkivskyi derzhavnyi universytet kharchuvannia ta torhivli, Kharkiv.

23. Kacy G.D., Kojuda L.I., Krivich T.V., Skljarevskaja E.S. (2008), Biologicheskie metody ocenki produktivnosti zhivotnyh, Lugansk.

24. Niemirich A., Melnyk O., Petrusha O., Havrysh A., Koval O. (2016), Technological properties of the powder made from jerusalem artichoke obtained by the method of drying with mixed heat supply, Eureka: Life Science, 3, pp. 3-7. 